\title{
Sistem Informasi Monitoring dan Pemeliharaan Penggunaan Scada (Supervisory Control and Data Acquisition)
}

\author{
Arief budiman $^{1, *}$, jupriyadi $^{2}$, sunariyo $^{3}$ \\ ${ }^{1,2,3}$ Fakultas Teknik dan Ilmu Komputer, Universitas Teknokrat Indonesia \\ Email: 1," arief.budiman10@teknokrat.ac.id, ${ }^{2 j u p r i y a d i @ t e k n o k r a t . a c . i d, ~}{ }^{3}$ sunariyo@gmail.com
}

\begin{abstract}
Abstrak-Supervisory Control and Data Acquisition (SCADA) merupakan fasilitas yang digunakan dalam pengawasan, pengontrolan dan pengumpulan data. Pengelolaan pemeliharaan penggunaan alat SCADA di PT PLN (Persero) Unit induk Pelaksana Pengatur Distribusi Lampung dirasa masih belum optimal. Dalam melaksanakan kegiatan pemeliharaan alat SCADA mulai dari pengisian perintah kerja, pengisian form pemeliharaan alat SCADA sampai dengan penyusunan laporan masih menggunakan buku dan google doc. Hal tersebut menyebabkan timbulnya beberapa permasalahan, seperti membutuhkan waktu yang lama untuk melakukan pencatatan dan pencarian data pemeliharaan. Oleh karena itu, penelitian ini dilakukan untuk merancang dan membangun sistem informasi manajemen monitoring pemeliharaan penggunaan alat SCADA berbasis web menggunakan framework codeigniter pada PT PLN (Persero) Unit Induk Pelaksana Pengatur Distribusi Lampung. Perancangan sistem informasi dilakukan menggunakan metode pengembangan sistem Web Engineering. Model tersebut dipilih karena sistem informasi ini berbasis web, sehingga pendekatan penelitian yang digunakan akan lebih tepat. Kerangka kerja yang digunakan web engineering menggunakan kerangka kerja umum rekayasa perangkat lunak yang aktivitasnya meliputi komunikasi, perencanaan, pemodelan, pembangunan dan deployment. Sistem akan dibangun menggunakan framework codeigniter dengan menggunakan bahasa pemrograman PHP dan MySQL sebagai basis datanya. Hasil dari pengujian sistem menunjukkan bahwa sistem informasi manajemen monitoring pemeliharaan penggunaan alat SCADA dapat berfungsi sesuai dengan yang diharapkan, dengan dukungan library yang lengkap pada framework codeigniter dapat mempercepat pembangunan sistem informasi manajemen monitoring dan pemeliharaan penggunaan alat SCADA. Implementasi sistem ini diperuntukan bagi empat aktor yang terlibat. Keempat aktor tersebut adalah admin, Petugas Pelaksana, Supervisi dan Manager Bagian. Pengujian sistem menunjukkan bahwa rancangan secara fungsional menghasilkan nilai sebesar $79,74 \%$ dengan kriteria baik, dan dinilai layak untuk diterapkan.
\end{abstract}

Kata Kunci: Pengawasan, Pemeliharaan, Data, framework, codeigniter

Abstract - Supervisory Control and Data Acquisition (SCADA) is a facility used in monitoring, controlling and collecting data. The maintenance management of the use of SCADA tools at PT PLN (Persero) is still not optimal. In carrying out maintenance activities for SCADA tools, starting from filling out work orders, filling out SCADA equipment maintenance forms to preparing reports, they still use books and google docs. This causes several problems, such as taking a long time to record and search for maintenance data. Therefore, this research was conducted to design and build a monitoring management information system for the use of web-based SCADA tools using the codeigniter framework at PT PLN (Persero) Lampung Distribution Regulatory Implementation Unit. The design of the information system is carried out using the Web Engineering system development method. The model was chosen because this information system is web-based, so the research approach used will be more appropriate. The framework used by web engineering uses a general software engineering framework whose activities include communication, planning, modeling, development and deployment. The system will be built using the codeigniter framework using the PHP programming language and MySQL as the database. The results of the system test show that the management information system for monitoring the use of SCADA tools can function as expected, with the support of a complete library in the codeigniter framework, it can accelerate the development of a management information system for monitoring and maintaining the use of SCADA tools. The implementation of this system is intended for the four actors involved. The four actors are admin, Implementing Officer, Supervision and Section Manager. System testing shows that the functional design produces a value of $79.74 \%$ with good criteria, and is considered feasible to be applied.

Keywords: Monitoring, Maintenance, Data, framework, codeigniter

\section{PENDAHULUAN}

Perusahaan Listrik Negara (PLN) merupakan salah satu perusahaan milik negara yang memberikan pelayanan kepada calon pelanggan dan masyarakat dalam penyediaan jasa yang berhubungan dengan penjualan tenaga listrik satu-satunya di Indonesia. Peningkatan kebutuhan listrik melonjak dengan tinggi dan cepat, khususnya kebutuhan listrik bagi rumah tangga dan diiringi pula dengan tingkat kepuasan masyarakat menjadi lebih tinggi lagi sebagai akibat dari meningkatnya pendapatan masyarakat yang maju dan modern [1].

Pelanggan yang tersebar diberbagai tempat, menimbulkan kendala tersendiri dalam penyaluran atau distribusi sampai di tempat konsumen, dalam hal ini perlu penanganan teknis tersendiri, yang disesuaikan dengan kebutuhan listrik dan letak geografis suatu daerah. Pelayanan merupakan unsur yang sangat penting di dalam usaha meningkatkan kepuasan konsumen. Pada dasarnya posisi pelayanan ini merupakan fakor pendukung terhadap aktivitas pemasaran jasa PLN. Untuk itu PLN memberikan perhatian khusus kepada kegiatan pelayanan dalam hal pemenuhan kebutuhan listrik pelanggan agar dalam pelaksanaannya dapat memuaskan pelanggannya. 
Pelayanan yang diberikan memenuhi permintaan pelanggan, maka pelanggan akan merasa puas dan bila jasa pelayanan berada di bawah tingkat yang diharapkan, pelanggan akan merasa kurang atau tidak puas. Pelanggan yang merasa tidak puas terhadap kualitas atau pelayanan yang diberikan, maka dengan sendirinya akan menceritakan kepada orang lain sebagai komplain atas ketidakpuasannya yang nantinya akan merugikan pihak PLN itu sendiri.

Pada PLN Distribusi Lampung dalam menghasilkan pasokan listrik yang andal, dibutuhkan pengawasan, pengontrolan, dan pengumpulan data yang akurat. SCADA merupakan singkatan dari Supervisory Control and Data Acquisition. Maksud dari SCADA yaitu pengawasan, pengendalian dan pengumpulan data. Fasilitas SCADA diperlukan untuk melaksanakan pengusahaan tenaga listrik terutama pengendalian operasi secara real time. Peralatan SCADA secara umum meliputi, yaitu Master Station, Remote Station dan Media Komunikasi. Master Station, berada di HMI (Human Machine Interface); Remote Station, berada di plan (suatu rancang bangun alat); dan Media Komunikasi, yang menghubungkan antara Master Station dengan Remote Station. Selain itu dibutuhkan pula peralatan IED (Intelligent Electronics Device) berupa Power Meter untuk pengukuran arus dan tegangan.

Pada saat ini sistem SCADA pada PT PLN (Persero) Unit Pelaksana Pengatur Distribusi Lampung masih belum optimal, karena hasil data pemeliharaan SCADA yang diterima kemudian diolah kembali masih dalam bentuk google docs. Dalam melaksanakan kegiatan pemeliharaan alat SCADA pelaksana pekerjaan melakukan pengisian perintah kerja kemudian di approve oleh assisten manager. Kemudian pelaksana pekerjaan melakukan pemeliharaan alat SCADA, setelah selesai melakukan pemeliharaan alat SCADA pelaksana pekerja melakukan pengisian form pemeliharaan masih dalam bentuk kertas, kemudian di approve oleh supervisor dan manajer bagian, kemudian laporan pemeliharaan di simpan dalam bentuk google docs. Hal tersebut menyebabkan timbulnya beberapa masalah, diantaranya, tidak adanya data yang mudah untuk menampilkan informasi mengenai pengguna/pemakai SCADA, tidak terdapat sistem informasi mengenai pemeliharaan SCADA. Selain itu pencatatan secara manual juga dapat menyebabkan rawan terjadi kesalahan dalam pencatatan data. Penggunaan google docs dapat diakses dari berbagai tempat, namun juga belum memberikan kemudahan dalam pelaporan yang diperlukan dalam proses maintenance yang ada.

Perancangan Sistem SCADA mengacu pada fungsi dari komputer sebagai salah satu alat untuk membantu menyelesaikan masalah. Perancangan bangun sistem ini akan menggunakan pengembangan perangkat lunak dengan model web engineering. Model tersebut dipilih karena sistem informasi ini berbasis web, sehingga pendekatan penelitian yang digunakan akan lebih tepat jika menggunakan web engineering. Karena web enginnering digunakan untuk menciptakan aplikasi web yang berkualitas tinggi. Rekayasa web mengadaptasi rekayasa perangkat lunak dalam hal konsep dasar yang menekankan pada aktifitas teknis dan manajemen. Namun demikian adaptasi tidak secara utuh, tapi dengan perubahan dan penyesuaian. Rekayasa web gabungan antara web publishing (suatu konsep yang berasal dari printed publishing) dan aktifitas rekayasa perangkat lunak. Dikatakan demikian karena desain sebuah aplikasi web menekankan pada desain grafis, desain informasi, teori hypertext, desain sistem dan pemrograman.

Kelebihan dari web engineering dibandingkan dengan pengembangan web biasa yaitu terletak pada prinsip requirement. Dari salah satu riset yang telah dilakukan sebelumnya oleh Powel tahun 1998, model modified waterfall dan spiral merupakan model yang terbaik dibandingkan dengan model yang lain. Selain itu rekayasa web juga berprinsip kepada pengembangan sebuah aplikasi yang sering dikenal dengan Web Application Development (WAD). Bagian dari proses yang dilakukan oleh WAD adalah terkait dengan teknik yang digunakan $[2]$.

\section{METODE PENELITIAN}

\subsection{Tahapan Penelitian}

Berisi Kerangka pemikiran adalah konsep pemecahan masalah yang telah diidentifikasi atau dirumuskan. Kerangka pemikiran dapat dilihat pada Gambar 1. Pada penelitian ini dilaksanakan dalam lima tahapan, dimulai dari komunikasi, perencanaan, pemodelan, pengembangan dan pengembangan. Tahapan penelitian ini menyesuaikan dengan kerangka kerja dari Web Engineering. Kelima tahapan yang menjadi acuan penelitian ini berguna dalam memastikan hasil yang nantinya dapat digunakan pada PLN Distribusi Lampung. Untuk itu dalam penelitian ini salah satu yang menjadi kunci adalah komunikasi dengan tempat penelitian agar tahapan berikutnya menjadi lebih baik dan sesuai dengan kebutuhan penyelesaian masalah yang diperlukan. 


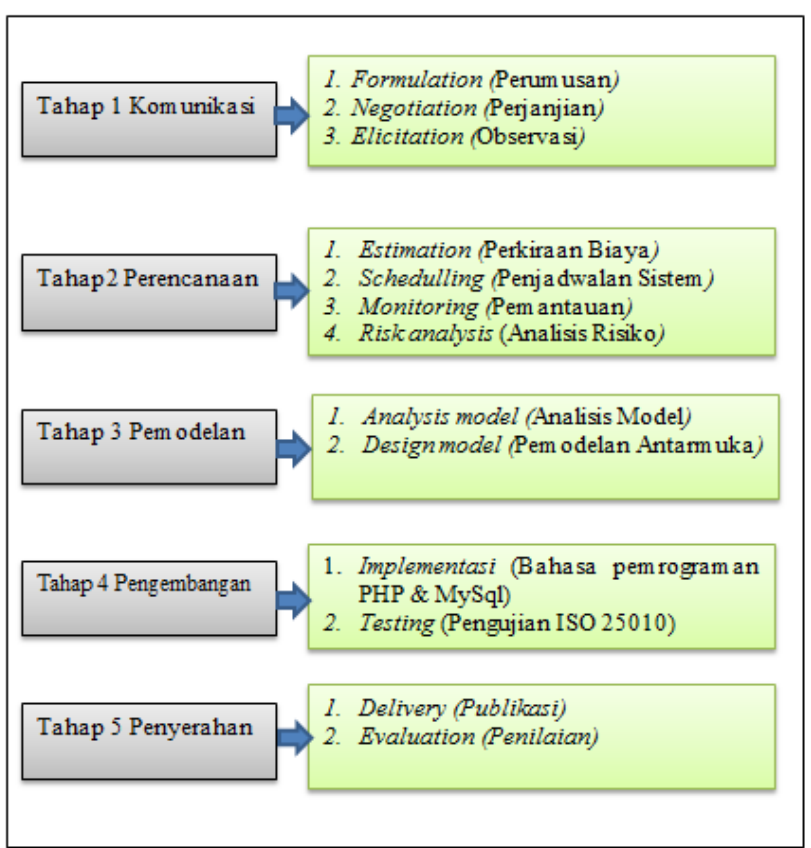

Gambar 1. Tahapan Penelitian

\subsection{Metode Web engineering}

Web engineering atau rekayasa web adalah suatu proses pendekatan rekayasa yang digunakan untuk membuat sistem dan aplikasi berbasis web yang berkualitas. Menurut [3], web engineering menyediakan sebuah kerangka kerja secara agile yang memiliki aturan-aturan untuk membangun aplikasi berbasis web berkualitas industri. Sifat agile pada web engineering mampu mengakomodasi perubahan cepat dan berkelanjutan saat mengembangkan aplikasi berbasis web [4]. Kerangka kerja web engineering dapat terlihat pada Gambar 2.

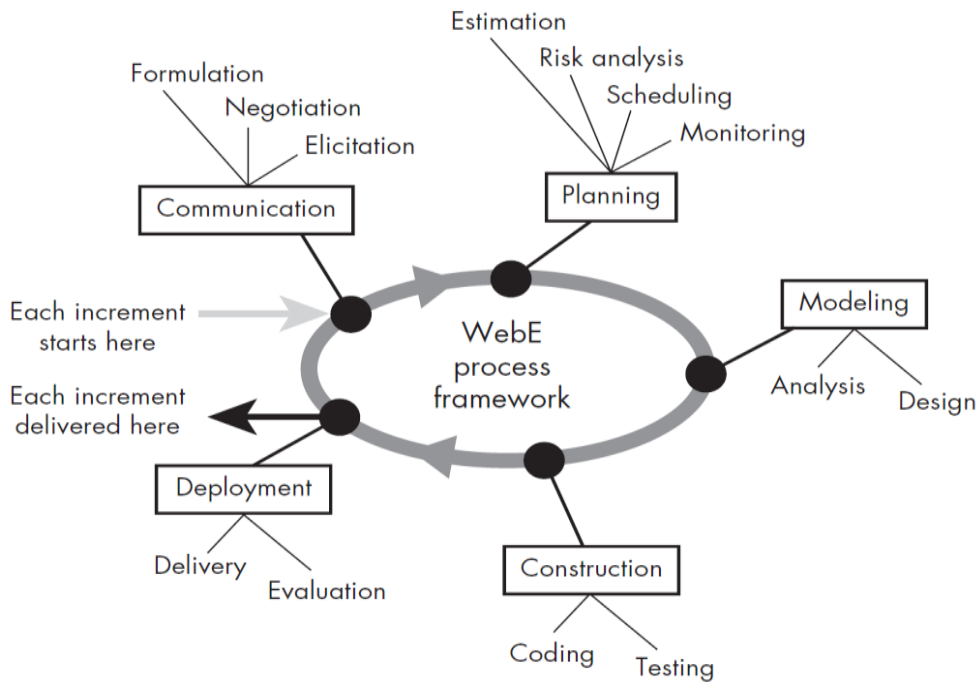

Gambar 2. Kerangka kerja web engineering

\subsection{Sistem Monitoring}

Monitoring didefinisikan sebagai siklus kegiatan yang mencakup pengumpulan, peninjauan ulang, pelaporan, dan tindakan atas informasi suatu proses yang sedang diimplementasikan [5]. Umumnya, monitoring digunakan dalam pemeriksaan antara kinerja dan target yang telah ditentukan.

Monitoring ditinjau dari hubungan terhadap manajemen kinerja adalah proses terintegrasi untuk memastikan bahwa proses berjalan sesuai rencana (on the track) [6]. Monitoring dapat memberikan informasi keberlangsungan 
proses untuk menetapkan langkah menuju ke arah perbaikan yang berkesinambungan. Pada pelaksanaannya, monitoring dilakukan ketika suatu proses sedang berlangsung. Level kajian sistem monitoring mengacu pada kegiatan per kegiatan dalam suatu bagian [7].

\subsection{Sistem SCADA}

Sistem adalah kumpulan dari beberapa alat atau komponen yang membentuk suatu kesatuan dan bekerja bersamasama. Sedangkan SCADA merupakan singkatan dari Supervisory Control and Data Acquisition.

1. Supervisory $=$ Pengawasan

2. Control $=$ Kontrol

3. Data Acquisition $=$ Permintaan/Pengiriman Data

Jadi, sistem SCADA adalah suatu kesatuan dari beberapa peralatan yang saling berkomunikasi untuk menjalankan fungsi pengawasan, pengontrolan, dan pengumpulan data dari suatu proses [8]. Prinsip dasar Sistem SCADA ada 2, yaitu :

1. Memantau dan mengontrol semua peralatan yang terdapat pada suatu sistem dari jarak jauh.

2. SCADA bekerja mengumpulkan informasi, kemudian mentransfernya ke sentral dengan membawa datadata dan sinyal kontrol (status) yang kemudian diperagakan pada sejumlah layar operator.

SCADA merupakan suatu sistem untuk pengendalian dan pemantauan jarak jauh. Dalam sistem tenaga listrik SCADA bertujuan untuk membantu mendapatkan sistem pengoperasian yang optimum [9]. Pada umumnya proses pengendalian pada sistem tenaga listrik jarak jauh terdiri atas 4 macam, yaitu :

1. Pengendalian buka/tutup perangkat pemutus daya, pemisah serta start/stop dari generator.

2. Pengendalian perangkat-perangkat regulator seperti pengaturan set point atau menaikkan dan menurunkan posisi tap changer.

3. Pemantau dan pengaturan beban.

4. Pengendalian yang dilakukan secara otomatis untuk keseragaman dan pengendalian perintah berurutan, misalnya merubah konfigurasi jaringan.

\subsection{Fungsi SCADA}

Sistem SCADA dapat difungsikan dari pusat kontrol melalui komputer utama (main computer). Dari tampilan pada layar komputer utama inilah dispatcher dapat melakukan pengawasan dan pengendalian terhadap jaringan listrik, khususnya jaringan distribusi bagi PT. PLN (Persero) Distribusi Jakarta Raya dan Tangerang. Pada saat dispatcher melakukan suatu perintah maka komputer utama mengirimkan sinyal ke remote terminal unit (RTU) melalui media komunikasi [10].

\subsection{Alat Pengembang Sistem}

\section{Framework}

Framework merupakan kerangka kerja yang memudahkan programmer untuk membuat sebuah aplikasi sehingga programmer akan lebih mudah melakukan perubahan (customize) terhadap aplikasinya dan dapat memakainya kembali untuk aplikasi lain yang sejenis [11]. Menurut Purbadian (2016) mengatakan bahwa "Framework adalah kerangka kerja atau sekumpulan file-file yang sudah ter-include, yang mana di dalam file tersebut terdapat perintah kode program dan fungsi dasar untuk melakukan tugas tertentu”.

Dari pengertian di atas dapat disimpulkan bahwa framework merupakan kerangka kerja yang di dalamnya terdapat kode program dan fungsi dasar untuk melakukan tugas tertentu yang memudahkan programmer untuk membuat aplikasi dan dapat digunakan kembali untuk aplikasi lain yang sejenis [13].

\section{Codeigniter}

Codeigniter adalah sebuah framework yang dibuat menggunakan bahasa pemrograman $P H P$ yang bertujuan untuk memudahkan para programmer web untuk membuat atau mengembangkan aplikasi berbasis web. Codeigniter memiliki eksekusi tercepat dibandingkan dengan framework lainnya. Codeigniter bersifat open source dan menggunakan model basis MVC (Model View Controller), yang merupakan model konsep modern saat ini. Codeigniter juga menawarkan banyak library yang dapat digunakan [14].

\section{PHP}

PHP (Perl Hypertext Preprocessor) adalah pemograman script yang memuat dokumen HTML secara on the fly di eksekusi di server web, dokumen HTML yang dihasilkan dari suatu aplikasi bukan dokumen HTML yang dibuat dengan editor teks atau editor HTML [15]. 


\section{HASIL DAN PEMBAHASAN}

Sistem yang dikembangkan dalam penelitian ini diperuntukkan bagi empat aktor yang terlibat dalam sistem. Keempat aktor tersebut antara lain Admin, Pelaksana, Supervisor dan Manager Bagian. Berikut adalah hasil implementasi sistem sesuai dengan role aktor masing-masing.

\subsection{Implementasi Form Halaman Login Admin}

Halaman login merupakan halaman yang pertama kali ditampilkan ketika user mengakses sistem informasi pemeliharaan alat SCADA. User harus login menggunakan username dan password sesuai dengan level user-nya agar dapat masuk ke dalam sistem pada Gambar 3.

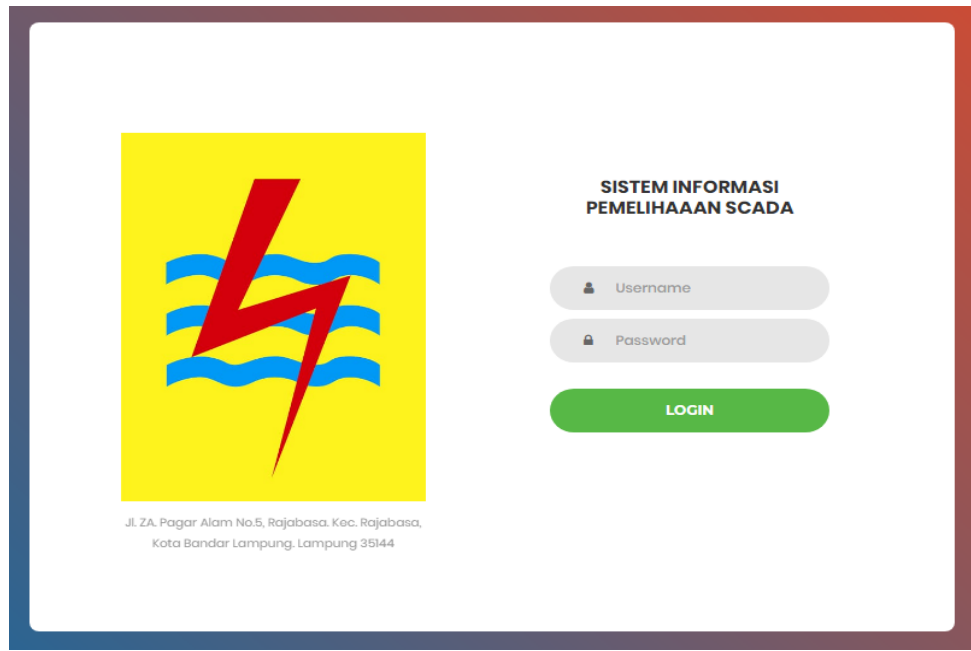

Gambar 3. Implementasi Form Halaman Login

1. Halaman Pelaksana

Halaman pelaksana merupakan halaman untuk menambah pelaksana yang akan melakukan pemeliharaan alat SCADA, NIP akan digunakan sebagai user untuk melakukan login, halaman tambah pelaksana baru dapat dilihat pada gambar Gambar 4.

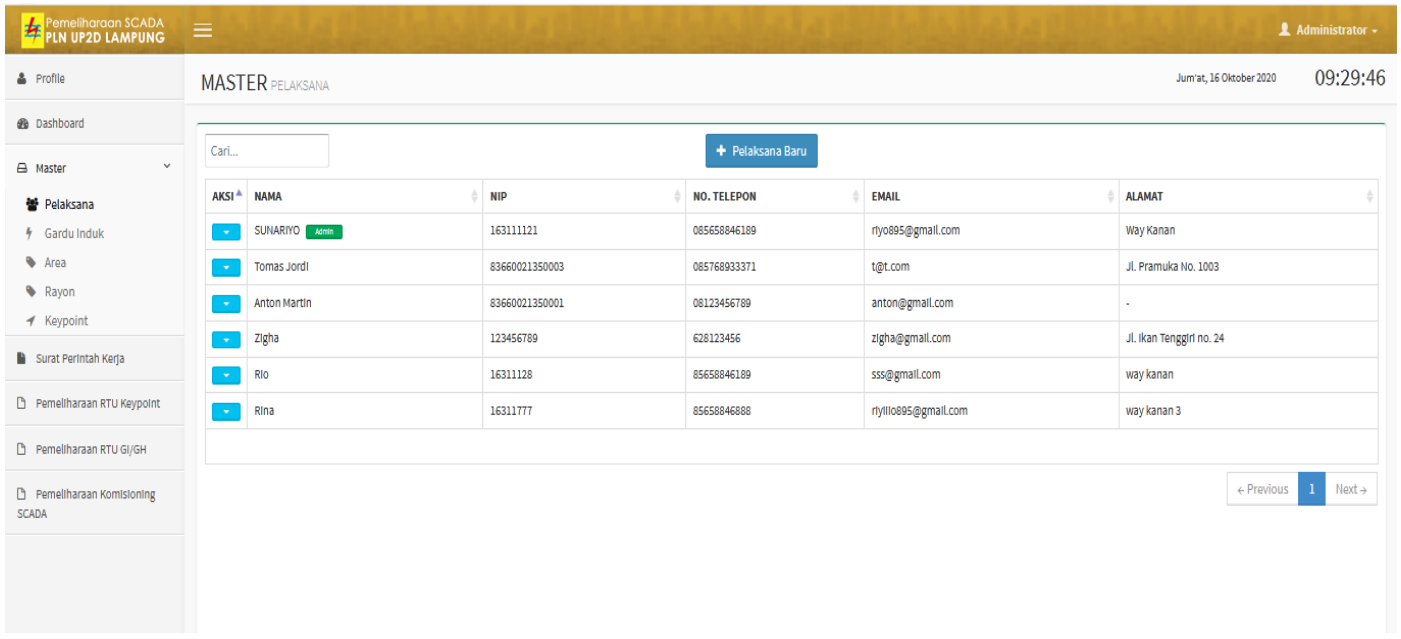

Gambar 4. Halaman Tambah Pelaksana Baru

2. Halaman Tambah Gardu Induk

Halaman tambah gardu induk merupakan gardu induk yang akan dilakukan pemeliharaan alat SCADA, halaman tambah gardu induk baru dapat dilihat pada Gambar 5 berikut. 


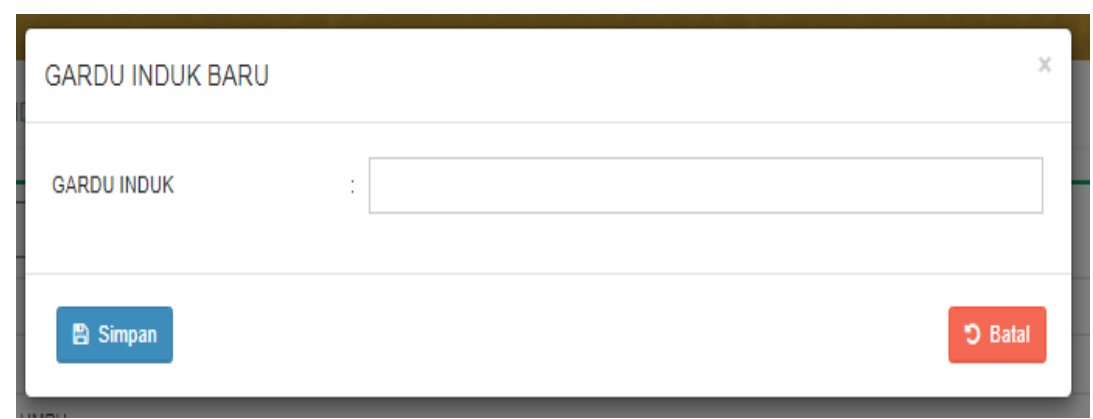

Gambar 5 Halaman Tambah Gardu Induk

Setelah melakukan penambahan gardu induk baru maka halaman gardu induk baru dapat dilihat pada gambar 6 berikut:

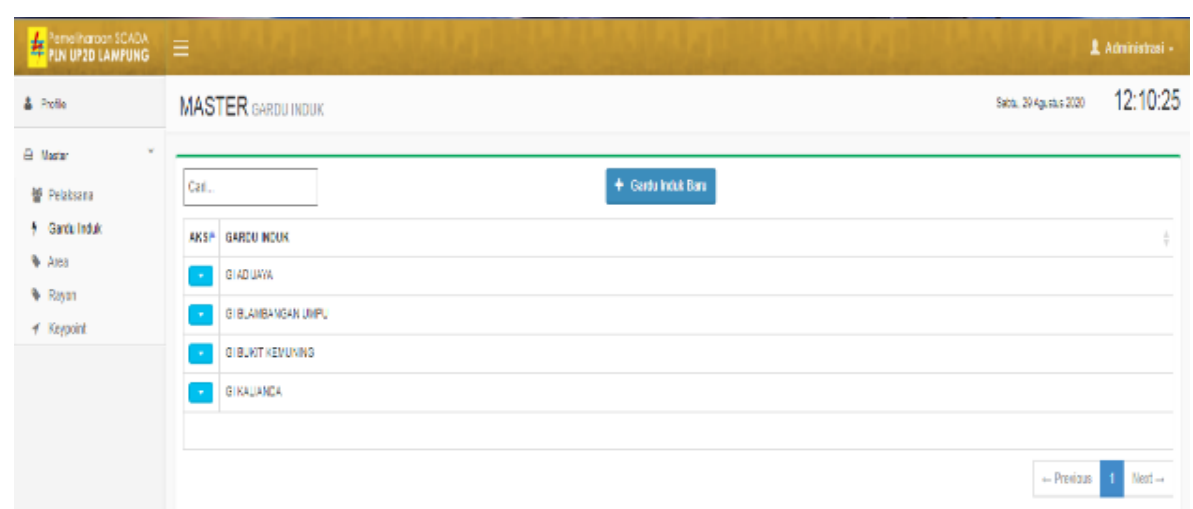

Gambar 6. Halaman Setelah Tambah Gardu Induk

3. Halaman Tambah Area

Halaman tambah area merupakan area yang akan dilakukan pemeliharaan alat SCADA, halaman tambah area baru dapat dilihat pada gambar 7 berikut:

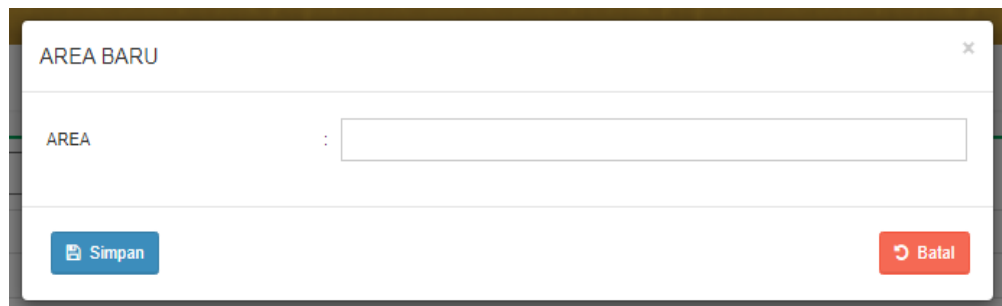

Gambar 7. halaman Tambah Area Baru

Setelah melakukan penambahan area baru maka halaman area baru dapat dilihat pada gambar 8 berikut:

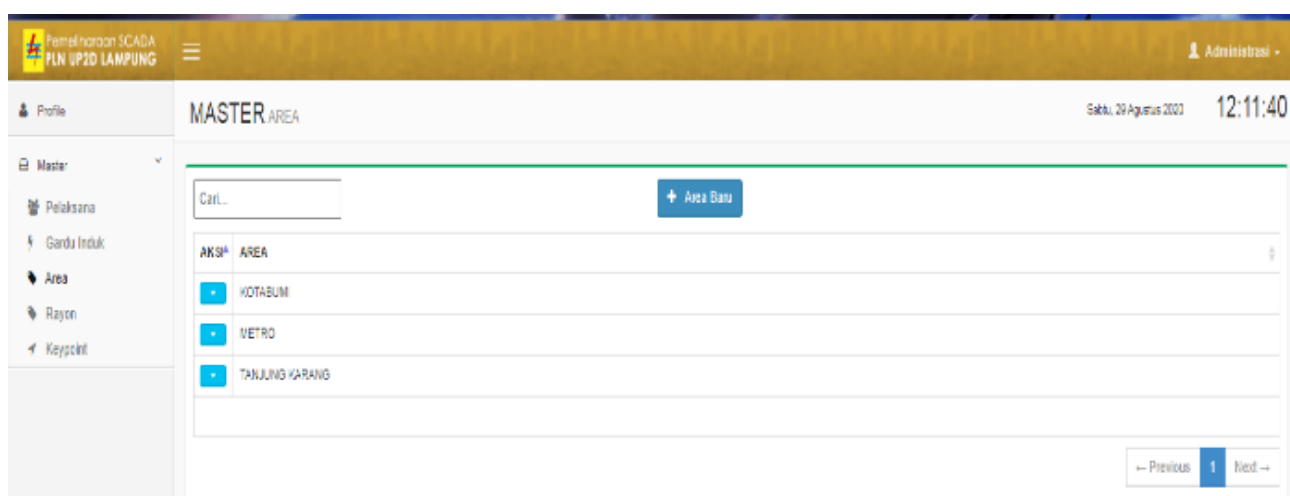

Gambar 8. halaman Setelah Tambah Area Baru

4. Halaman Tambah Rayon

Halaman tambah rayon merupakan area yang akan dilakukan pemeliharaan alat SCADA, halaman tambah rayon baru dapat dilihat pada gambar 9 berikut: 


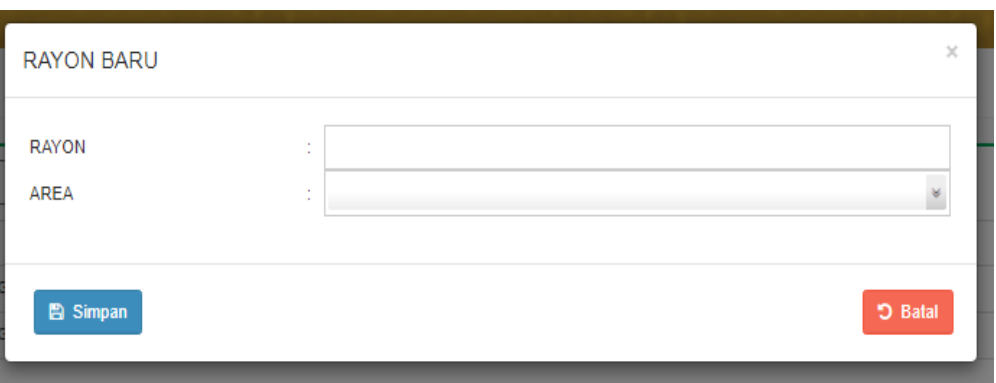

Gambar 9. Halaman Tambah Rayon Baru

Setelah melakukan penambahan Rayon baru maka halaman area baru dapat dilihat pada gambar 10 berikut:

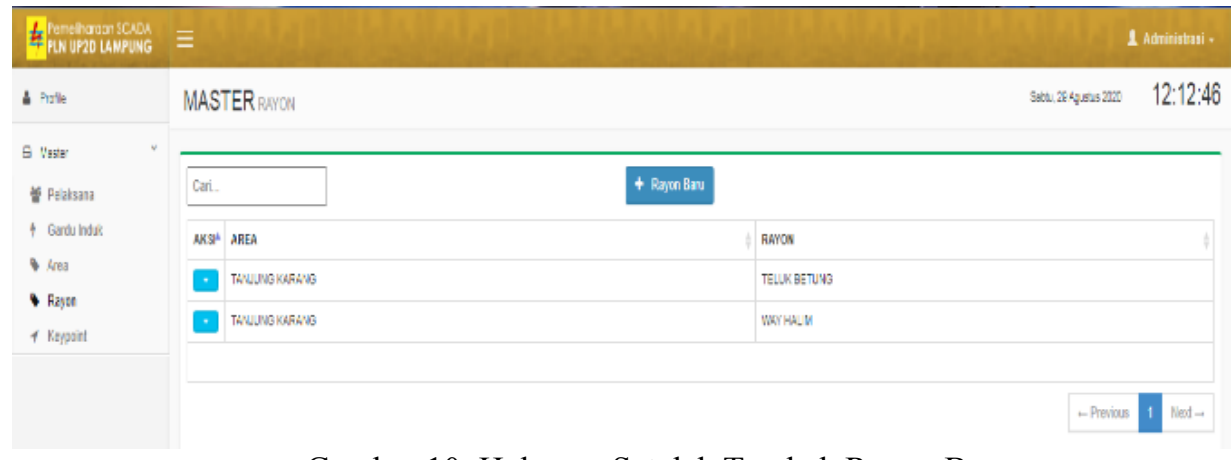

Gambar 10. Halaman Setelah Tambah Rayon Baru

5. Halaman Tambah Keypoint

Halaman tambah Keypoint merupakan pemilihan gardu induk dan rayon area pemeliharaan yang akan dilakukan pemeliharaan alat SCADA, halaman tambah Keypoint baru dapat dilihat pada gambar 11 berikut :

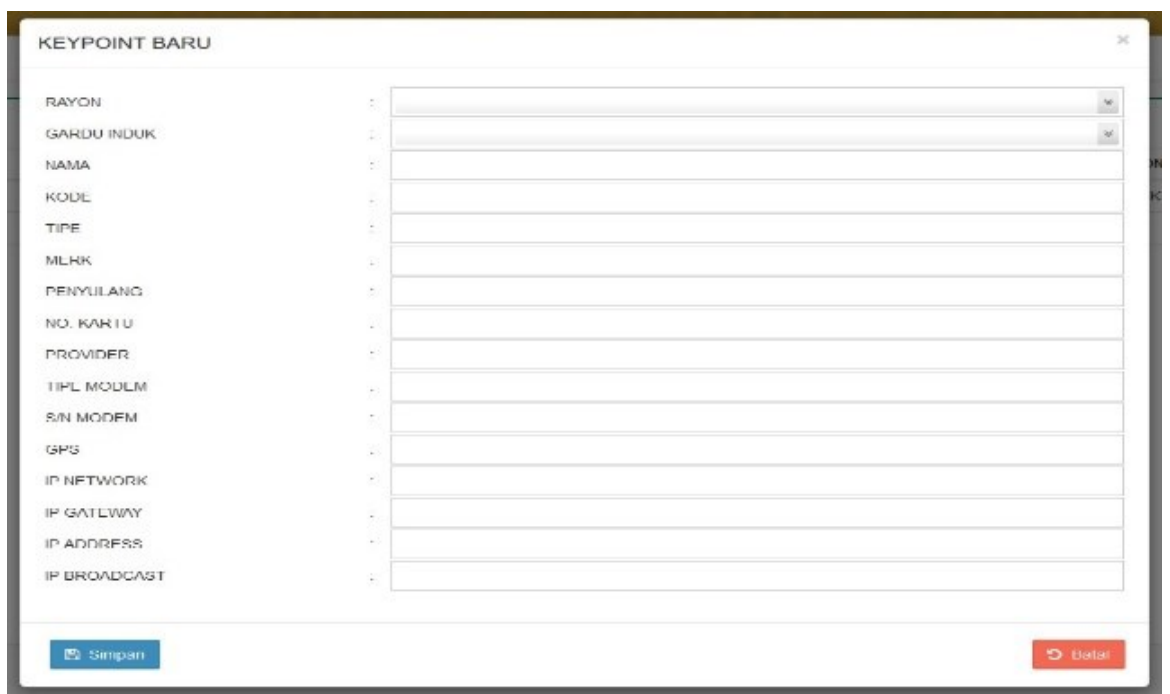

Gambar 11. Halaman Tambah Keypoint

Pada halaman keypoint diisi pada saat pengerjaan dengan menentukan rayon pada masing-masing gardu induk yang dipelihara. Penyesuaian kode, nama dan pengaturan jaringan diisi sesuai dengan data. Setelah melakukan penambahan keypoint baru maka halaman keypoint baru dapat dilihat pada gambar 12 berikut: 


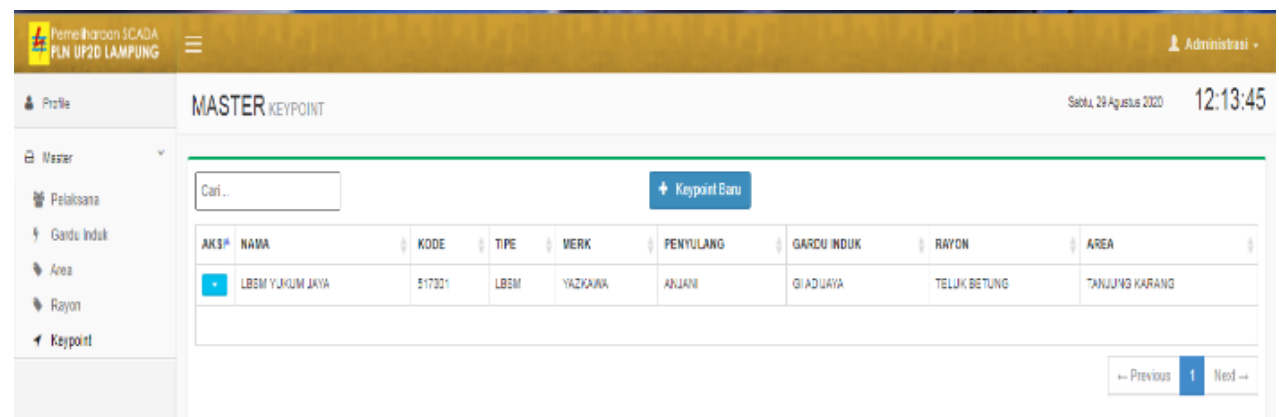

Gambar 12 Halaman Setelah Tambah keypoint

\subsection{Implementasi Halaman Supervisor}

Supervisor dapat melakukan pengisian form perintah kerja, untuk disetujui oleh manager bagian. Surat perintah kerja berisi informasi terkait pemeliharaan SCADA. Surat perintah kerja ini nantinya akan digunakan oleh pelaksana dalam melaksanakan tugas pemeliharaan alat SCADA. Tampilan form perintah kerja dapat terlihat seperti pada Gambar 13.
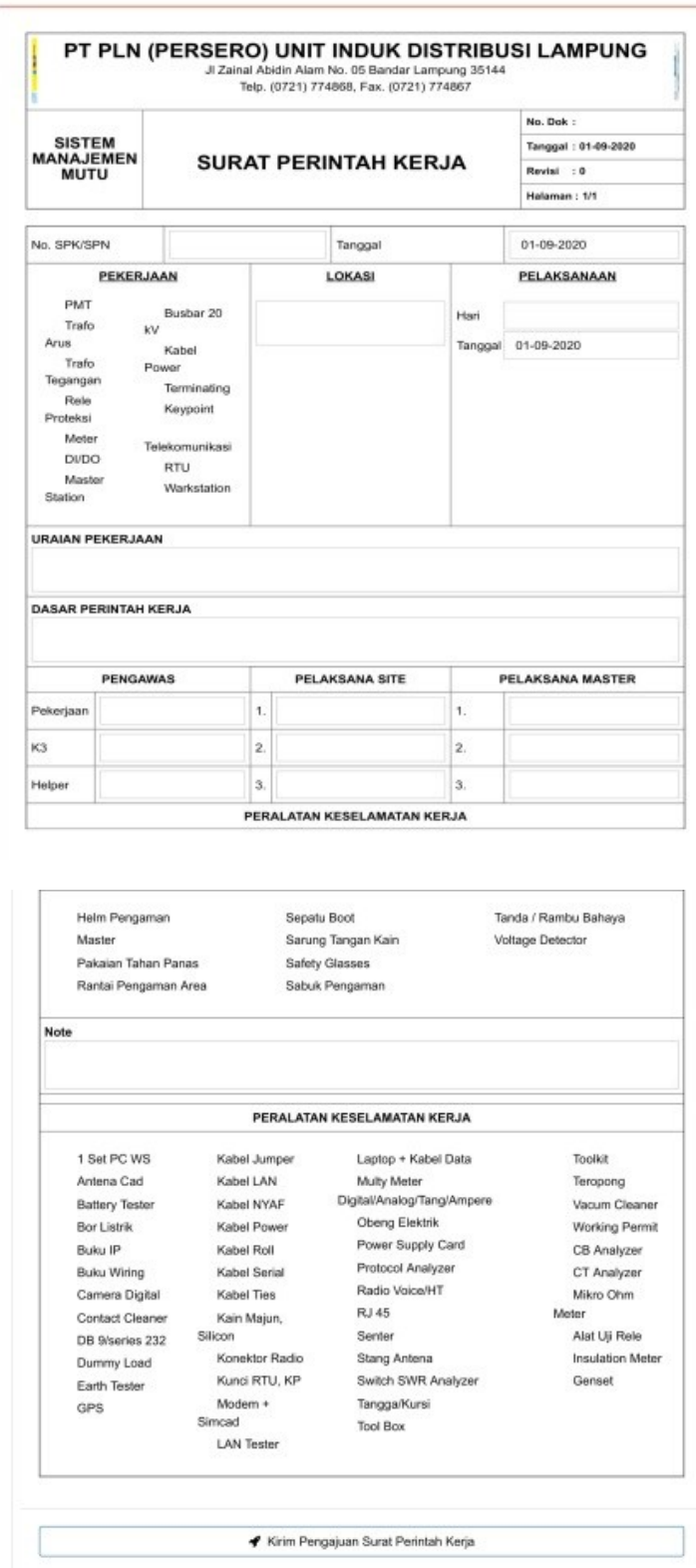

Gambar 13. Tampilan Perintah Kerja 
Setelah supervisor melakukan pengisian perintah kerja maka selanjutnya menunggu persetujuan dari manager bagian.

\subsection{Implementasi Halaman Manager Bagian}

Dalam melakukan pengisian perintah kerja yang telah dilakukan oleh supervisor setelah di setujui oleh manager bagian, dapat dilihat pada Gambar 14.

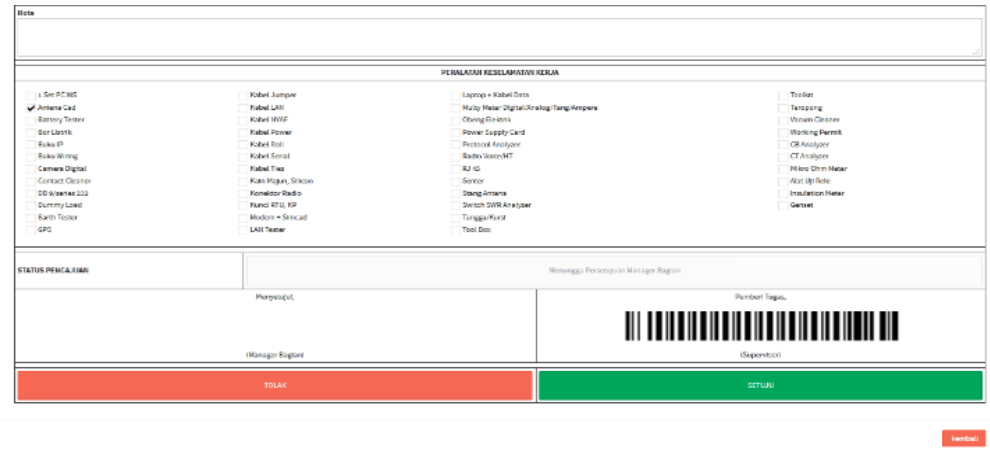

Gambar 14. Halaman Perintah Kerja Persetujuan Manager Bagian

Kemudian manager bagian dapat melihat formulir perintah kerja setelah di isi oleh supervisor kemudian jika di tolak maka supervisor dapat melakukan pengisian perintah kerja kembali, halaman setelah persetujuan manager bagian dapat dilihat pada Gambar 15.

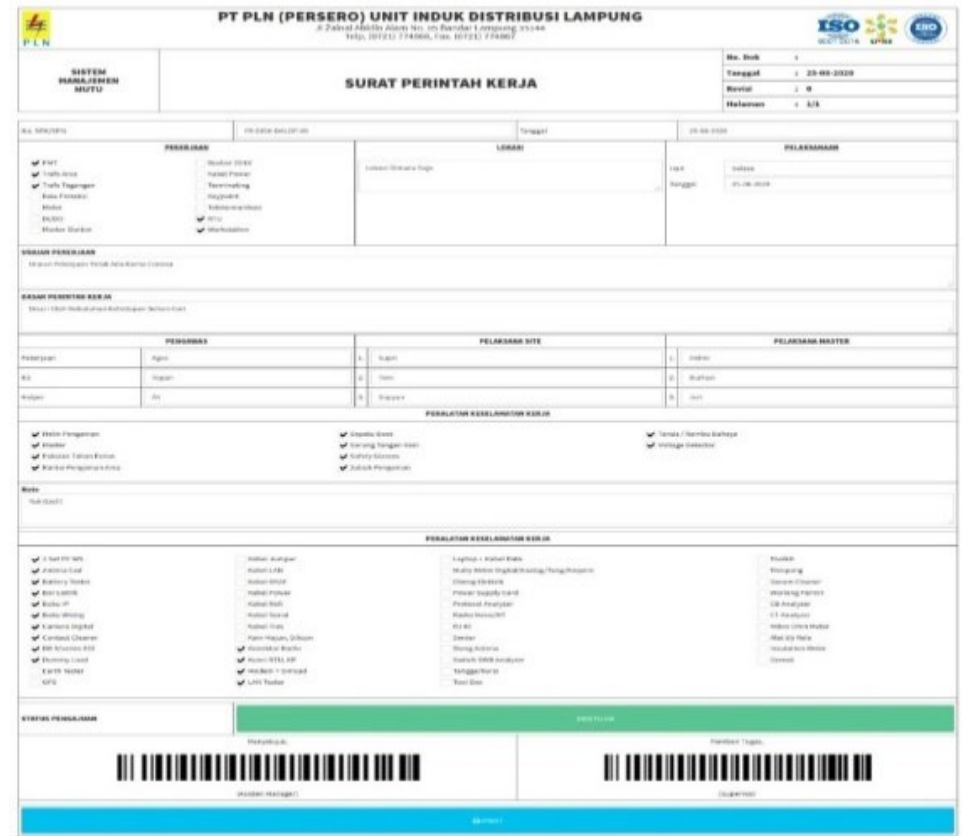

Gambar 15. Tampilan validasi perintah kerja manajer

\subsection{Implementasi Halaman Pelaksana}

Pelaksana dapat melakukan pengisian data terhadap pemeliharaan alat SCADA yang dilakukan. Pada halaman pemeliharaan, setelah perintah kerja mendapat persetujuan kemudian pelaksana melakukan pemeliharaan alat SCADA, setelah pelaksana melakukan pekerjaan maka pelaksana dapat melakukan pengisian form pemeliharaan yang meliputi pemeliharaan RTU Keypoint, RTU GI/GH, dan Komisioning SCADA.

\section{Pemeliharaan RTU Keypoint}

Form tambah Pemeliharan RTU Keypoint merupakan form yang dapat digunakan oleh Pelaksana untuk menambah/menginput data Pemeliharaan di lapangan. Implementasi form tambah pemeliharaan RTU Keypoint dapat dilihat pada Gambar 16. 


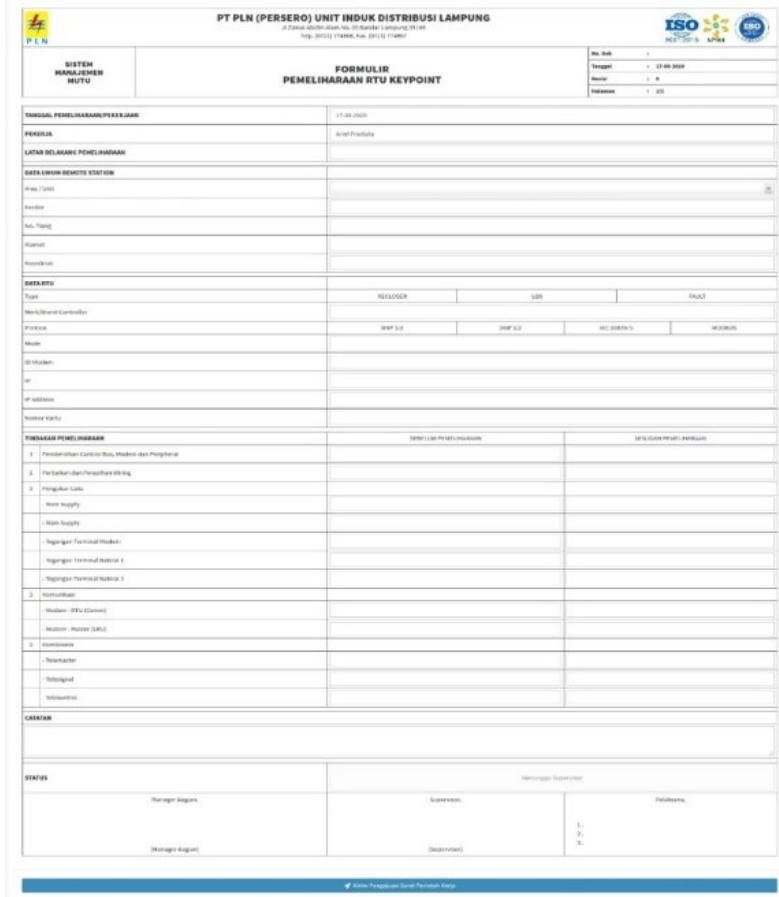

Gambar 16. Halaman Tambah Pemeliharaan Keypoint

\section{Pemeliharaan RTU GI/GH}

Form tambah Pemeliharan RTU GI/GH merupakan form yang dapat digunakan oleh Pelaksana pekerjaan untuk menambah/menginput data Pemeliharaan RTU GI/GH. Implementasi form tambah pemeliharaan RTU GI/GH dapat dilihat pada Gambar 17

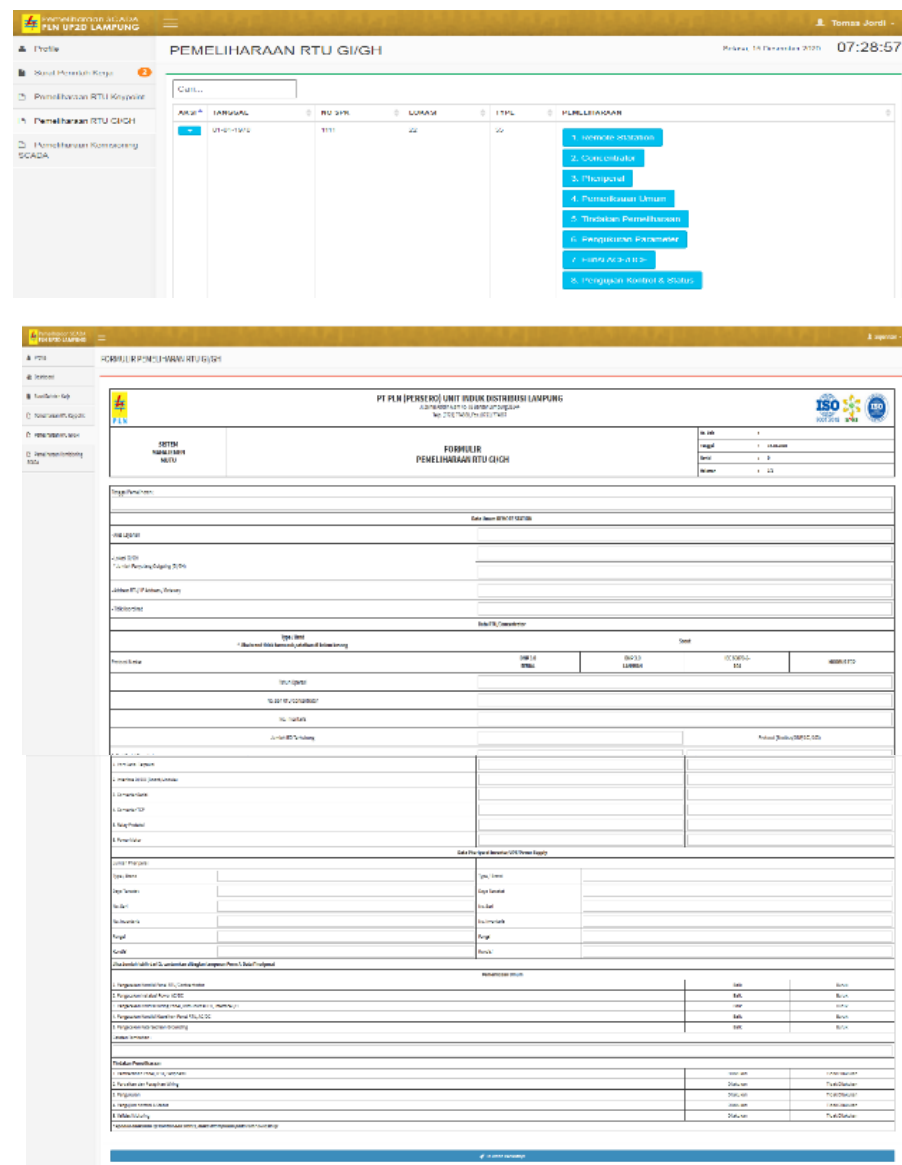

Gambar 17. Pemeliharaan RTU GI/GH 


\section{Pemeliharaan Komisioning SCADA}

Form tambah Pemeliharan Komisioning SCADA merupakan form yang dapat digunakan oleh Pelaksana pekerjaan untuk menambah/menginput data Pemeliharaan Komisioning SCADA. Implementasi pemeliharaan Komisioning SCADA dapat dilihat pada gambar 18.

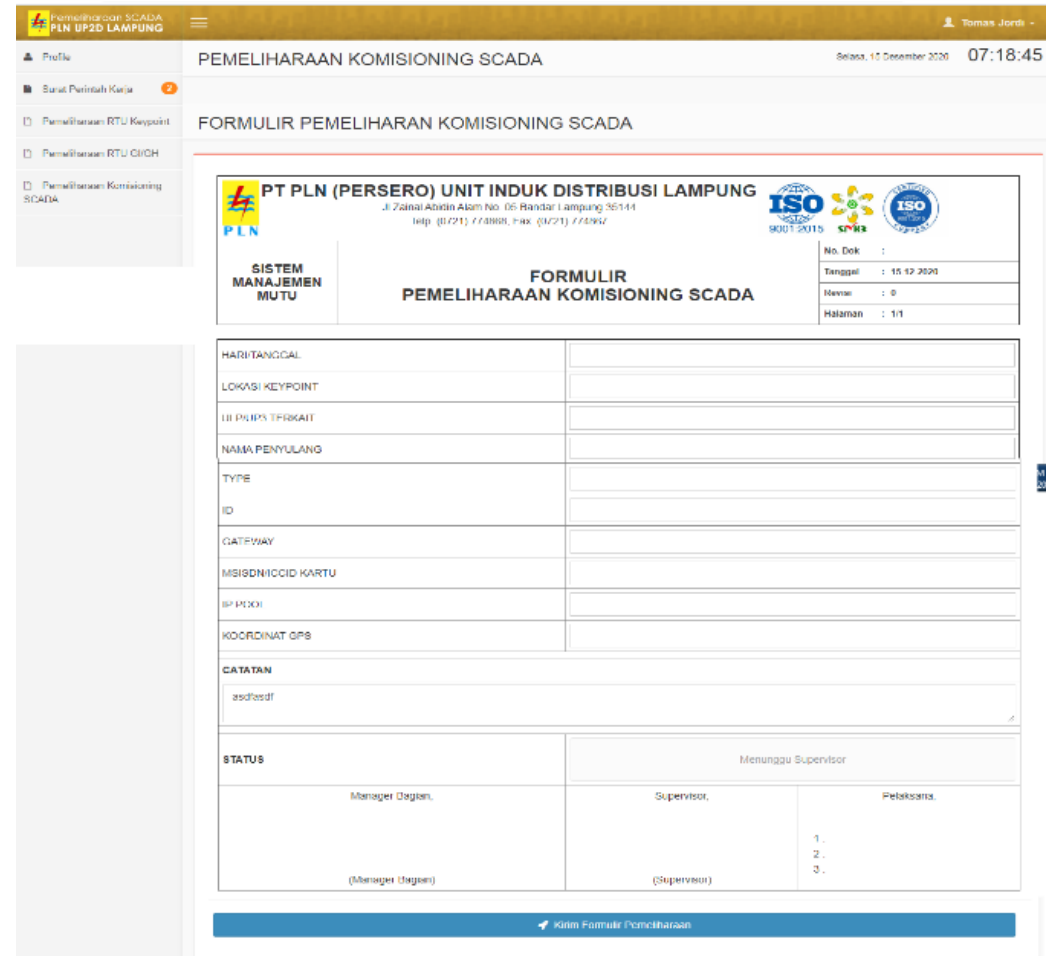

Gambar 18. Pemeliharaan Komisioning SCADA

\section{Mengisi data pemeliharaan pada formulir komisioning}

Data pemeliharaan komisioning SCADA yang telah diisi oleh pelaksana pekerja, akan menjadi laporan yang digunakan dalam memantau pekerjaan yang telah dilakukan. Form ini juga telah menyesuaikan dengan standar Form yang digunakan sebelumnya. Hasil dari laporan akan menampilkan data sesuai dengan signal type, nama point dan nilai dari pengaturan remote. Data tersebut sudah diketahui oleh supervisor dan manager bagian. Tampilan formulir yang diisi dapat dilihat pada Gambar 19.

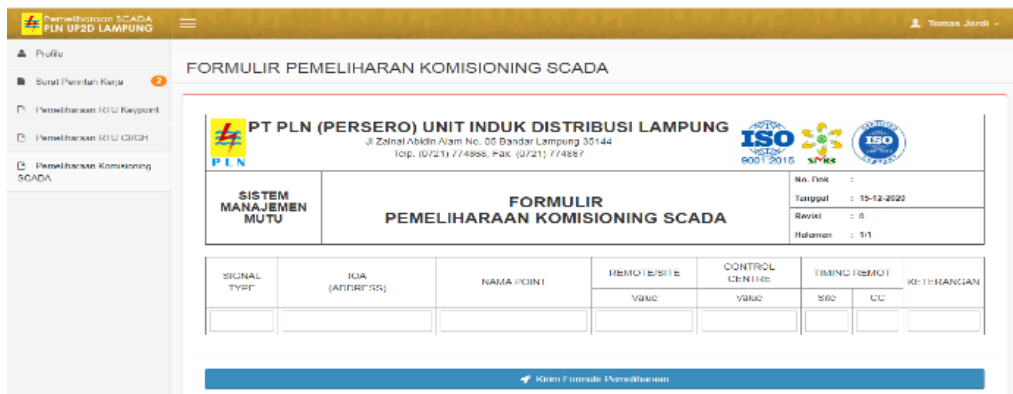

Gambar 19. Mengisi data pemeiharaan pada formulir komisioning

\section{KESIMPULAN}

Berdasarkan hasil perancangan sistem informasi manajemen monitoring dan pemeliharaan penggunaan alat SCADA menggunakan framework codeigniter pada PT PLN (persero) Unit Pelaksana Pengatur Distribusi Lampung yang sudah dilakukan, maka dapat ditarik kesimpulan bahwa dengan dukungan library yang lengkap pada framework codeigniter dapat mempercepat pembangunan sistem informasi manajemen monitoring dan pemeliharaan penggunaan alat SCADA.

Petugas yang berkaitan dengan pemeliharaan alat SCADA dapat melakukan proses kerja secara terintegrasi antar bagian. Petugas yang melakukan penanganan teknis dapat dimonitor proses kerja melalui system. Sehingga 
walaupun petugas melakukan penanganan di tempat yang tersebar, para supervisi dan manajer bagian dapat mengetahui proses yang berlangsung melalui sistem. Hal ini diharapkan dapat mempermudah para pengawas dalam memantau pekerjaan pemeliharaan alat SCADA dan penanganan keluhan dari pelanggan. Kepuasan pelanggan akan pasokan listrik menjadi lebih mudah termonitor melalui sistem dengan melihat status alat SCADA yang ada di setiap daerah.

Proses administrasi berupa laporan yang harus diisi oleh petugas maupun yang harus divalidasi oleh supervisi dan manajer bagian, dapat terdokumentasi dengan cepat dan baik melalui system. Form yang sebelumnya harus diisi secara manual dapat tergantikan dengan pengisian melalui system. Laporan secara berkala pun dapat terlihat dan terorganisir dengan baik pada database sistem.

\section{UCAPAN TERIMAKASIH}

Terima kasih disampaikan kepada pihak Universitas Teknokrat Indonesia yang selalu mendukung civitas akademik dalam mengembangkan ilmu dan pengetahuan khususnya dalam penelitian.

\section{REFERENCES}

[1] PLN, “Operasi dan Pemeliharaan Sistem Scada,” Jakarta Selatan, 2009.

[2] U. Proboyekti, "Rekayasa Web.” pp. 1-6, 2017.

[3] D. L. Pressman, Roger S, Web Engineering a Practitioner's Approach. New York: MacGraw-Hill, 2009.

[4] R. S. Pressman and B. R. Maxim, Software Engineering a Practitioner's Approach, Eight edit. McGraw-Hill, 2015.

[5] M. A. Gumelar B and E. Ariyanto, "Implementasi Scada Untuk Monitoring Dan Controling Serta Koordinasi Sistem Proteksi Gardu Induk Sistem 1,5 Breaker Pada Gardu Induk Tegangan Ekstra Tinggi Berbasis Arduino Mega 2560 Dengan Tampilan Hmi," Gema Teknol., vol. 19, no. 3, p. 14, 2017, doi: 10.14710/gt.v19i3.21880.

[6] N. Harun, "Evaluasi Monitoring Sistem Tenaga Listrik dengan Menggunakan Scada Gateway dan Remote Terminal Unit," vol. XX, no. xx, pp. 1-42, 2013, [Online]. Available: https://adoc.tips/evaluasimonitoring-sistem-tenaga-listrik-dengan-menggunakan.html.

[7] A. Fikri, R. Susana, and D. Nataliana, "Monitoring Model Sistem Pengepakan dan Penyortiran Barang Berbasis SCADA," J. Reka Elkomika, vol. 2, no. 4, pp. 285-300, 2014.

[8] A. A. N. Aufa and T. Yuwono, “OPTIMALISASI HMI SCADA UNTUK MONITORING DAN KONTROL REPEATER RADIO KOMUNIKASI MENGGUNAKAN MODEM GPRS INTEK J65iX,” Gema Teknol., vol. 18, no. 1, p. 27, 2014, doi: 10.14710/gt.v18i1.8812.

[9] N. A. Z, A. Hidayat, and W. Kasoep, "Perancangan Human Machine Interface Berbasis SCADA pada PT . PLN ( Persero ) Unit Pengatur Beban ( UPB ) SUMBAGTENG,” J. Tek. Elektro, vol. 1, 2016.

[10] M. Soleh, "Desain Sistem SCADA Untuk Peningkatan Pelayanan Pelanggan Dan Efisiensi Operasional Sistem Tenaga Listrik di APJ Cirebon," J. Telekomun. dan Komput., vol. 5, no. 1, p. 25, 2017, doi: 10.22441/incomtech.v5i1.1132.

[11] M. F. Setiadi, "Tutorial Codeigniter Untuk Pemula," Angewandte Chemie International Edition, 6(11), 951-952. p. 63, 2018.

[12] Y. Purbadian, Trik Cepat Membangun Aplikasi Berbasis Web dengan Framework CodeIgniter. Yogyakarta: Andi Offset, 2016.

[13] A. O. Sari, A. Abdilah, and Sunarti, Buku Web Programming. Jakarta: Gaha Ilmu - Universitas Bina Sarana Informatika, 2019.

[14] A. Subagia, Kolaborasi Codeigniter dan Ajax dalam Perancangan CMS. Jakarta: PT. Elex Media Komputindo, 2018.

[15] R. Sabarudin and W. E. Jayanti, Jago Ngoding Pemrograman Web dengan PHP Untuk Pemula, no. January. Surabaya: CV. Kanaka Media, 2019. 